\title{
The occurrence of anxiety, depression, and suicidal thoughts in patients with psoriasis
}

\section{Występowanie lęku, depresji oraz myśli samobójczych u chorych na łuszczycę}

Magdalena Stachecka', Teresa N. Rzepa², Joanna Furmańska ${ }^{3}$, Ryszard W. Żaba ${ }^{4}$

'University of Social Sciences and Humanities, Faculty in Poznan, Poland

${ }^{2}$ Psychotherapeutic Centre SENSterapia, Poznan, Poland

${ }^{3}$ Institute of Psychology, University of Szczecin, Poland

${ }^{4}$ Department of Dermatology and Venereology, Poznan University of Medical Sciences, Poland

'Uniwersytet Humanistycznospołeczny SWPS, Wydział Zamiejscowy w Poznaniu, Polska

${ }^{2}$ Ośrodek Psychoterapeutyczny SENSterapia, Poznań, Polska

${ }^{3}$ Instytut Psychologii, Uniwersytet Szczeciński, Polska

${ }^{4}$ Katedra Dermatologii i Wenerologii, Uniwersytet Medyczny w Poznaniu, Polska

\author{
CORRESPONDING AUTHOR/ \\ ADRES DO KORESPONDENCJI: \\ dr Joanna Furmańska \\ Instytut Psychologii \\ Uniwersytet Szczeciński \\ ul. Krakowska 69 \\ 71-017 Szczecin \\ e-mail: furmanska-joanna@wp.pl
}

\begin{abstract}
Introduction. Psychological factors have a significant impact on the course of psoriasis. Its symptoms and chronic nature contribute to numerous emotional problems.

Objective. To evaluate the differences within the scope of social anxiety, depression and suicidal thoughts among healthy people and people diagnosed with psoriasis.

Material and methods. The research involved 120 participants who filled in the State-Trait Anxiety Inventory (STAI), Beck Depression Inventory and the author's survey on suicidal thoughts.

Results. According to all the three factors, statistically significant differences were found between the individuals with psoriasis and healthy people. Patients with psoriasis were characterized by higher levels of depression, suicidal thoughts, and a higher level of anxiety as a state. The level of anxiety as a trait was found to be insignificant. Another significant factor was gender. Women with psoriasis had higher levels of depression and suicidal thoughts than the healthy women. The level of social anxiety was found to be insignificant. Inverse correlations were demonstrated among the male participants. Men diagnosed with psoriasis had higher levels of social anxiety as a state compared to the control group. The differences between the levels of depression and suicidal thoughts proved to be insignificant.

Conclusions. Psychological counseling should play an important role in management of the long-term consequences of psoriasis. A psychologist's intervention should include motivating the patient to start treatment, assistance in adaptation to the disease and improving the life quality by effective coping with tension and stress.
\end{abstract}

\section{STRESZCZENIE}

Wprowadzenie. Czynniki psychologiczne mają istotny wpływ na przebieg łuszczycy. Jej objawy i przewlekły charakter przyczyniają się do występowania problemów emocjonalnych.

Cel pracy. Sprawdzenie, czy pomiędzy osobami zdrowymi i chorymi 
na łuszczycę zachodzą różnice pod względem lęku, skłonności do depresji i myśli samobójczych.

Materiał i metody. Badaniami objęto 120 osób, w tym 60 chorych na łuszczycę i 60 zdrowych. Zastosowano Inwentarz stanu $i$ cechy lęku (STAI), Skalę depresji Becka (BDI) oraz autorską ankietę do badania myśli samobójczych.

Wyniki. Stwierdzono statystycznie istotną różnicę w występowaniu lęku jako stanu między osobami z łuszczycą a osobami z grupy kontrolnej. Nie wykazano różnicy w zakresie lęku jako cechy pomiędzy badanymi grupami, choć poziom tej zmiennej okazał się wyższy u chorych na łuszczycę niż u osób zdrowych. Średnia zaburzeń depresyjnych u chorych na łuszczycę jest wyższa niż u osób z grupy kontrolnej. Występowanie myśli samobójczych również okazało się czynnikiem statystycznie istotnie różniącym obie grupy. Stwierdzono znaczące różnice pomiędzy kobietami zdrowymi i chorymi na łuszczycę pod względem skłonności do depresji oraz występowania myśli samobójczych.

Wnioski. Pomoc psychologiczna odgrywa ważną rolę w zwalczaniu długotrwałych następstw łuszczycy. Interwencja psychologa powinna obejmować motywowanie pacjenta do podjęcia leczenia, pomoc w przystosowaniu się do choroby i poprawianiu jakości życia poprzez efektywne radzenie sobie $\mathrm{z}$ napięciem i stresem.

Key words: psoriasis, depression, suicidal thoughts, gender.

Słowa kluczowe: łuszczyca, lęk, depresja, myśli samobójcze, płeć.

\section{INTRODUCTION}

Psoriasis is one of the most common, non-contagious skin diseases, of a chronic and recurrent nature. They are accompanied by itching - one of the most onerous symptoms of psoriasis - which hinders sleep and everyday functioning. Skin lesions are often associated with an unhygienic lifestyle, which may cause aversion in the social environment $[1,2]$.

Psychological factors have a significant impact on the course of psoriasis. Its symptoms and chronic nature contribute to numerous emotional problems. Most often, psoriasis patients experience distress, apprehension, anxiety, irritability, embarrassment and shame. They usually show a lowered self-esteem and tend to withdraw from social life due to the need to mask the skin lesions and the fear of being stigmatized by other people. Thus, the disease evokes feelings of stigmatization and affects the life quality, limiting the person's social and occupational activities [3-5].

A sustained state of anxiety and incertitude in the context of the chronic disease that is bothersome to treat may lead to depressive disorders $[6,7]$. The risk of developing depressive disorders depends on the

\section{WPROWADZENIE}

Łuszczyca jest jedną z najczęstszych niezakaźnych chorób skóry o przewlekłym i nawrotowym przebiegu. Zmianom skórnym towarzyszy świąd - jeden z najbardziej dokuczliwych objawów łuszczycy utrudniający sen i codzienne funkcjonowanie. Objawy skórne są często kojarzone z niehigienicznym stylem życia, co może powodować niechęć ze strony otoczenia społecznego [1, 2].

Czynniki psychologiczne mają istotny wpływ na przebieg łuszczycy. Jej objawy i przewlekły charakter przyczyniają się do występowania problemów emocjonalnych. Najczęściej chorzy odczuwają przygnębienie, niepokój, lęk, drażliwość, zakłopotanie i wstyd. Zazwyczaj mają obniżoną samoocenę i przejawiają tendencję do wycofywania się z życia społecznego ze względu na konieczność maskowania zmian skórnych i lęk przed oceną innych ludzi. Choroba wywołuje więc poczucie stygmatyzacji i wpływa na jakość życia, ograniczając aktywność społeczną, zawodową i towarzyską [3-5].

Utrzymywanie się stanu lękowej niepewności w zakresie tak długotrwałej i uciążliwej w leczeniu choroby jak łuszczyca może powodować zaburzenia depresyjne [6, 7]. Ryzyko ich wystąpienia jest uwa- 
size and location of skin lesions and the treatment length [8]. An important risk factor for depression development in the course of psoriasis is touch deprivation, as people often avoid even shaking hands when they see psoriatic lesions [9, 10]. Moreover, depression may occur as a result of psoriasis and it may lead to aggravation of its symptoms. Therefore, depression is considered to be secondary or primary to psoriasis [11] and 5\% of psoriasis patients (women more often than men) were found to have attempted suicide $[12,13]$. A decision to take one's own life is associated with depressive disorders and helplessness with regard to recurring symptoms of the disease [10].

Itching and skin lesions that develop in the course of psoriasis may contribute to deterioration of the patient's well-being, lowering of the mood, depressive disorders and suicidal thoughts, which not only lead to self-stigmatization, but also disturb normal social and occupational functioning.

\section{OBJECTIVE}

It was decided to find out whether there are differences between healthy persons and psoriasis patients with regard to anxiety as a state and as a trait, tendency to depression and suicidal thoughts. Additionally, the gender factor was taken into account.

\section{MATERIAL AND METHODS}

After obtaining consent from the Research Ethics Committee of the Poznan University of Medical Sciences (no. 122/15), a research study was conducted involving 60 psoriasis patients hospitalized in the Dermatology Department at the Heliodor Święcicki University Hospital. The control group included 60 students from one of the universities in Poznań. The groups were made up of equal $(50 \%)$ proportions of men and women; pairs of subjects were selected according to the gender and age criteria. In the psoriasis group, the mean age was $41.95 \pm 13.74$ years, where the mean age of the women was $47.30 \pm 13.75$, and of the men $36.60 \pm 11.65$ years. In the control group, the mean age was $41.65 \pm 12.76$ years. The women's mean age in this group was $47.10 \pm 12.52$ years, and the men's was $36.20 \pm 10.64$ years.

The following tools were applied to achieve the research objective: 1) State-Trait Anxiety Inventory (STAI) to measure anxiety understood as a temporary state, and as a relatively permanent personality trait [14]; 2) Beck Depression Inventory (BDI) to measure tendency to depression [15]; 3) the author's survey for examination of suicidal thoughts which consisted of 6 detailed questions, e.g. Have you imagined com- runkowane wielkością i rozmieszczeniem zmian skórnych oraz okresem leczenia [8]. Ważnym czynnikiem ryzyka rozwoju depresji w przebiegu łuszczycy jest deprywacja dotyku, gdyż ludzie często unikają podania ręki na widok zmian łuszczycowych $[9,10]$. Depresja może pojawić się w następstwie łuszczycy oraz powodować zaostrzenie jej objawów. Uznaje się, że depresja może być wtórna lub pierwotna do łuszczycy [11] oraz że 5\% chorych na łuszczyce (częściej kobiety niż mężczyźni) podejmuje próby samobójcze $[12,13]$. Decyzja o odebraniu sobie życia jest związana z zaburzeniami depresyjnymi i bezradnością wobec nawracających symptomów choroby [10].

Świąd i zmiany skórne występujące w przebiegu łuszczycy mogą się przyczyniać do pogorszenia samopoczucia i obniżenia nastroju, zaburzeń depresyjnych i myśli samobójczych, co nie tylko prowadzi do samostygmatyzacji, lecz również zakłóca normalne funkcjonowanie społeczne i zawodowe.

\section{CEL PRACY}

Postanowiono sprawdzić, czy pomiędzy osobami zdrowymi a chorymi na łuszczycę zachodzą różnice pod względem lęku, skłonności do depresji i myśli samobójczych. Dodatkowo zdecydowano uwzględnić wpływ płci.

\section{MATERIA I I METODY}

Po uzyskaniu zgody Komisji Bioetycznej Uniwersytetu Medycznego w Poznaniu (nr 122/15) do badania włączono 60 chorych na łuszczycę przebywających na Oddziale Dermatologii Szpitala Klinicznego im. Heliodora Święcickiego. Grupa kontrolna składała się z 60 studentów poznańskiej uczelni. Zadbano o zachowanie odpowiedniej proporcji kobiet i mężczyzn (po 50\%) oraz o dobór w grupach według kryterium płci i wieku. U chorych na łuszczycę średnia wieku wynosiła 41,95 $\pm 13,74$ roku, średni wiek kobiet - 47,30 $\pm 13,75$ roku, mężczyzn - 36,60 $\pm 11,65$ roku. W grupie kontrolnej średnia wieku wynosiła $41,65 \pm 12,76$ roku, średni wiek kobiet - 47,10 $\pm 12,52$ roku, mężczyzn - 36,20 $\pm 10,64$ roku.

Do realizacji celu badawczego użyto: 1) Inwentarza stanu $i$ cechy lęku (STAI), służącego do pomiaru lęku rozumianego jako stan przejściowy oraz jako względnie stała cecha osobowości [14]; 2) Skali depresji Becka (BDI), mierzącej skłonność do zaburzeń depresyjnych [15]; 3) autorskiej ankiety do badania myśli samobójczych, która składała się z 6 szczegółowych i wyskalowanych pytan (od „zdecydowanie tak” do „zdecydowanie nie”), np. „Czy miewał(a) Pan(i) fantazje na temat odebrania sobie życia? Czy w przeszłości przebył(a) Pan(i) próbę samobójczą?". 
mitting suicide? Have you made a suicide attempt? with calibrated answers (from "definitely yes" to "definitely not").

\section{Statistical analysis}

The statistical computations were performed using Statistica PL v. 10.0 software by StatSoft. Due to inconsistency with the normal distribution, the results were compared using the Mann-Whitney $U$ test, which was checked with the Shapiro-Wilk test. Results were considered statistically significant at $p<0.05$.

\section{RESULTS}

Among the psoriasis patients, the mean result measuring anxiety as a state was $41.22 \pm 9.12$, whereas the mean for anxiety as a trait was $41.67 \pm 9.56$. In the control group, the mean values of anxiety as a state and anxiety as a trait were respectively: 36.58 \pm 8.08 and $38.32 \pm 8.35$. A statistically significant difference was found ( $p=0.0075)$ between anxiety as a state among the psoriasis patients $(41.22 \pm 9.12)$ and anxiety as a state in the control group (36.58 \pm 8.08$)$. No differences were found with regard to anxiety as a trait between the two studied groups $(p=0.1457)$, although the level of this variable proved to be higher in the case of the psoriasis patients.

The mean of depressive disorders in the psoriasis group was $9.60 \pm 7.83$, whereas in the control group it was $5.78 \pm 5.50$. This difference is statistically significant $(p=0.0014)$.

Suicidal thoughts level in the psoriasis group was $3.65 \pm 2.82$, whereas in the control group it was $2.70 \pm 2.50$. This difference is statistically significant $(p=0.0455)$ (table 1$)$.

The level of depressive disorders among the female psoriasis patients $(11.07 \pm 8.58)$ was shown to be statistically significantly higher $(p=0.0058)$ than the level of depressive disorders among the women in the control group (6.20 \pm 5.58$)$. Also, suicidal thoughts proved to occur at a statistically significantly higher level $(p=0.0104)$ in female psoriasis patients $(3.83 \pm 2.77)$ compared to the women in the control group $(2.20 \pm 2.19)$. However, there were no differences between the women in the two groups with regard to anxiety as a state $(p=0.0632)$ or anxiety as a trait $(p=0.4670)$ (table 2).

A statistically significant difference was found $(p=0.0385)$ between anxiety as a state in the male psoriasis patients $(39.93 \pm 7.69)$ and anxiety as a state in the healthy men $(35.20 \pm 8.60)$. However, no differences were observed between these groups with regard to the level of anxiety as a trait $(p=0.1591)$, depressive disorders $(p=0.0850)$ or suicidal thoughts $(p=0.7524)$ (table 3).

\section{Analiza statystyczna}

Obliczenia statystyczne wykonano przy użyciu programu Statistica PL v. 10.0 firmy StatSoft. Wyniki porównano za pomocą testu Manna-Whitneya ze względu na brak zgodności z rozkładem normalnym, co sprawdzono przy użyciu testu Shapiro-Wilka. Wyniki uznano za istotne statystycznie przy $p<0,05$.

\section{WYNIKI}

U chorych na łuszczycę średnia lęku jako stanu wyniosła 41,22 $\pm 9,12$, natomiast średnia lęku jako cechy $41,67 \pm 9,56$. U osób z grupy kontrolnej średnie lęku jako stanu oraz lęku jako cechy wyniosły odpowiednio $36,58 \pm 8,08$ oraz $38,32 \pm 8,35$. Wykazano statystycznie istotną różnicę $(p=0,0075)$ pomiędzy lękiem jako stanem u osób z łuszczycą $(41,22$ $\pm 9,12)$ a lękiem jako stanem u osób z grupy kontrolnej $(36,58 \pm 8,08)$. Nie stwierdzono różnicy w zakresie lęku jako cechy pomiędzy badanymi grupami $(p=0,1457)$, choć poziom tej zmiennej okazał się wyższy u osób z łuszczycą niż u osób zdrowych.

Średnia zaburzeń depresyjnych u chorych na łuszczycę wyniosła 9,60 $\pm 7,83$, natomiast w grupie kontrolnej 5,78 $\pm 5,50$. Jest to różnica istotna statystycznie $(p=0,0014)$.

Występowanie myśli samobójczych u chorych na łuszczycę wynosiło $3,65 \pm 2,82$, a w grupie kontrolnej $2,70 \pm 2,50$. Jest to różnica istotna statystycznie $(p=0,0455)$ (tab. 1).

Stwierdzono, że poziom zaburzeń depresyjnych u kobiet z łuszczycą $(11,07 \pm 8,58)$ jest statystycznie istotnie wyższy $(p=0,0058)$ niż $\mathrm{u}$ kobiet $\mathrm{z}$ grupy kontrolnej $(6,20 \pm 5,58)$. Występowanie myśli samobójczych jest również statystycznie istotnie częstsze $(p=0,0104)$ u kobiet z łuszczycą $(3,83 \pm 2,77)$ niż $\mathrm{u}$ kobiet zdrowych $(2,20 \pm 2,19)$. Nie stwierdzono natomiast różnic pomiędzy kobietami należącymi do obu grup dla lęku jako stanu $(p=0,0632)$ oraz lęku jako cechy $(p=0,4670)$ (tab. 2$)$.

Wykazano statystycznie istotną różnicę ( $p=$ 0,0385) pomiędzy lękiem jako stanem u mężczyzn z łuszczycą $(39,93 \pm 7,69)$ a lękiem jako stanem u mężczyzn zdrowych $(35,20 \pm 8,60)$. Nie odnotowano różnic pomiędzy tymi grupami pod względem poziomu lęku jako cechy $(p=0,1591)$, zaburzeń depresyjnych $(p=0,0850)$ i występowania myśli samobójczych ( $p=0,7524)$ (tab. 3).

\section{OMÓWIENIE}

Stwierdzono statystycznie istotne różnice pomiędzy osobami zdrowymi i chorymi na łuszczycę w zakresie lęku jako stanu. Łuszczyca należy do chorób przewle- 
Table I. Anxiety as a state and as a trait, depressive disorders and suicidal thoughts in persons with psoriasis and in the control group Tabela I. Lęk jako stan i jako cecha, zaburzenia depresyjne oraz występowanie myśli samobójczych wśród osób z łuszczycą i w grupie kontrolnej

\begin{tabular}{|c|c|c|c|c|c|c|c|c|}
\hline & Group/Grupa & $\begin{array}{l}\mathrm{N} \text { u } \mathrm{m} b \text { e } \mathrm{r} \\
\text { of persons/ } \\
\text { Liczba osób }\end{array}$ & $\begin{array}{l}\text { Me a n / } \\
\text { Średnia }\end{array}$ & $\begin{array}{l}\text { Median/ } \\
\text { Mediana }\end{array}$ & $\begin{array}{l}\text { Minimum/ } \\
\text { Minimum }\end{array}$ & $\begin{array}{l}\text { Maximum/ } \\
\text { Maksimum }\end{array}$ & $\begin{array}{l}\text { Standard } \\
\text { deviation/ } \\
\text { Odchylenie } \\
\text { standardowe }\end{array}$ & $\begin{array}{l}P \text {-value/ } \\
\text { Wartość } P\end{array}$ \\
\hline \multirow[t]{2}{*}{$\begin{array}{l}\text { Anxiety as a state/ } \\
\text { Lęk jako stan }\end{array}$} & $\begin{array}{l}\text { Psoriasis patients/ } \\
\text { Osoby z łuszczycą }\end{array}$ & 60 & 41.22 & 40.00 & 22.00 & 66.00 & 9.12 & 0.0075 ** \\
\hline & $\begin{array}{l}\text { Control group/ } \\
\text { Grupa kontrolna }\end{array}$ & 60 & 36.58 & 37.00 & 20.00 & 56.00 & 8.08 & \\
\hline \multirow[t]{2}{*}{$\begin{array}{l}\text { Anxiety as a trait/ } \\
\text { Lęk jako cecha }\end{array}$} & $\begin{array}{l}\text { Psoriasis patients/ } \\
\text { Osoby z łuszczycą }\end{array}$ & 60 & 41.67 & 39.00 & 24.00 & 66.00 & 9.56 & 0.1457 \\
\hline & $\begin{array}{l}\text { Control group/ } \\
\text { Grupa kontrolna }\end{array}$ & 60 & 38.32 & 39.00 & 20.00 & 60.00 & 8.35 & \\
\hline \multirow{2}{*}{$\begin{array}{l}\text { Depressive } \\
\text { disorders/ } \\
\text { Zaburzenia } \\
\text { depresyjne }\end{array}$} & $\begin{array}{l}\text { Psoriasis patients/ } \\
\text { Osoby z łuszczycą }\end{array}$ & 60 & 9.60 & 7.00 & 0.00 & 38.00 & 7.83 & $0.0014 * *$ \\
\hline & $\begin{array}{l}\text { Control group/ } \\
\text { Grupa kontrolna }\end{array}$ & 60 & 5.78 & 4.00 & 0.00 & 19.00 & 5.50 & \\
\hline \multirow{2}{*}{$\begin{array}{l}\text { Suicidal thoughts/ } \\
\text { Występowanie myśli } \\
\text { samobójczych }\end{array}$} & $\begin{array}{l}\text { Psoriasis patients/ } \\
\text { Osoby z łuszczycą }\end{array}$ & 60 & 3.65 & 3.00 & 0.00 & 12.00 & 2.82 & $0.0455 *$ \\
\hline & $\begin{array}{l}\text { Control group/ } \\
\text { Grupa kontrolna }\end{array}$ & 60 & 2.70 & 2.00 & 0.00 & 10.00 & 2.50 & \\
\hline
\end{tabular}

Source: own research/Źródło: badanie własne. ${ }^{*} p<0.05 ;{ }^{*}{ }^{*} p 0.01$.

Table 2. Anxiety as a state and as a trait, depressive disorders and suicidal thoughts in women with psoriasis and in the control group Tabela 2. Lęk jako stan i jako cecha, zaburzenia depresyjne oraz występowanie myśli samobójczych u kobiet z łuszczycą i w grupie kontrolnej

\begin{tabular}{|c|c|c|c|c|c|c|c|c|}
\hline Women/Kobiety & & $\begin{array}{l}\text { Number of } \\
\text { persons/Licz- } \\
\text { ba osób }\end{array}$ & $\begin{array}{l}\text { Mean / } \\
\text { Średnia }\end{array}$ & $\begin{array}{l}\text { Median/ } \\
\text { Mediana }\end{array}$ & $\begin{array}{l}\text { Minimum/ } \\
\text { Minimum }\end{array}$ & $\begin{array}{l}\text { Maximum/ } \\
\text { Maksimum }\end{array}$ & $\begin{array}{l}\text { Standard de- } \\
\text { viation/Od- } \\
\text { chylenie stan- } \\
\text { dardowe }\end{array}$ & $\begin{array}{l}P \text {-value/ } \\
\text { Wartość } p\end{array}$ \\
\hline \multirow{2}{*}{$\begin{array}{l}\text { Anxiety as } \\
\text { a state/Lęk jako } \\
\text { stan }\end{array}$} & $\begin{array}{l}\text { Psoriasis patients/ } \\
\text { Osoby z łuszczycą }\end{array}$ & 30 & 42.50 & 40.00 & 22.00 & 66.00 & 10.33 & \multirow[t]{2}{*}{0.0632} \\
\hline & $\begin{array}{l}\text { Control group/ } \\
\text { Grupa kontrolna }\end{array}$ & 30 & 37.97 & 38.00 & 23.00 & 54.00 & 7.42 & \\
\hline \multirow{2}{*}{$\begin{array}{l}\text { Anxiety as } \\
\text { a trait/Lęk jako } \\
\text { cecha }\end{array}$} & $\begin{array}{l}\text { Psoriasis patients/ } \\
\text { Osoby z łuszczycą }\end{array}$ & 30 & 42.90 & 38.50 & 28.00 & 66.00 & 9.81 & \multirow[t]{2}{*}{0.4670} \\
\hline & $\begin{array}{l}\text { Control group/ } \\
\text { Grupa kontrolna }\end{array}$ & 30 & 40.33 & 41.00 & 26.00 & 60.00 & 7.67 & \\
\hline \multirow{2}{*}{$\begin{array}{l}\text { Depressive } \\
\text { disorders/ } \\
\text { Zaburzenia } \\
\text { depresyjne }\end{array}$} & $\begin{array}{l}\text { Psoriasis patients/ } \\
\text { Osoby z łuszczycą }\end{array}$ & 30 & 11.07 & 8.00 & 2.00 & 38.00 & 8.58 & \multirow[t]{2}{*}{$0.0058 * *$} \\
\hline & $\begin{array}{l}\text { Control group/ } \\
\text { Grupa kontrolna }\end{array}$ & 30 & 6.20 & 4.50 & 0.00 & 19.00 & 5.58 & \\
\hline \multirow{2}{*}{$\begin{array}{l}\text { Suicidal } \\
\text { thoughts/ } \\
\text { Występowanie } \\
\text { myśli } \\
\text { samobójczych }\end{array}$} & $\begin{array}{l}\text { Psoriasis patients/ } \\
\text { Osoby z łuszczycą }\end{array}$ & 30 & 3.83 & 4.00 & 0.00 & 12.00 & 2.77 & \multirow[t]{2}{*}{$0.0104 *$} \\
\hline & $\begin{array}{l}\text { Control group/ } \\
\text { Grupa kontrolna }\end{array}$ & 30 & 2.20 & 2.00 & 0.00 & 9.00 & 2.19 & \\
\hline
\end{tabular}

Source: own research/Źródło: badanie własne. ${ }^{*} p<0.05 ;{ }^{*}{ }^{*} p<0.01$.

\section{DISCUSSION}

Statistically significant differences were found between the healthy subjects and psoriasis patients with respect to anxiety as a state. The sources of anxiety may kłych, chorzy są narażeni na stygmatyzację, odczuwają wstyd i lęk przed odrzuceniem społecznym [16]. Prawie $60 \%$ pacjentów uważa, że ludzie przyglądają się im z powodu zmian na skórze. Stąd bierze się przekonanie, że inni traktują ich jak "trędowatych", których nie nale- 
Table 3. Anxiety as a state and as a trait, depressive disorders and suicidal thoughts in men with psoriasis and in the control group Tabela 3. Lęk jako stan i jako cecha, zaburzenia depresyjne oraz występowanie myśli samobójczych u mężczyzn z łuszczycą i w grupie kontrolnej

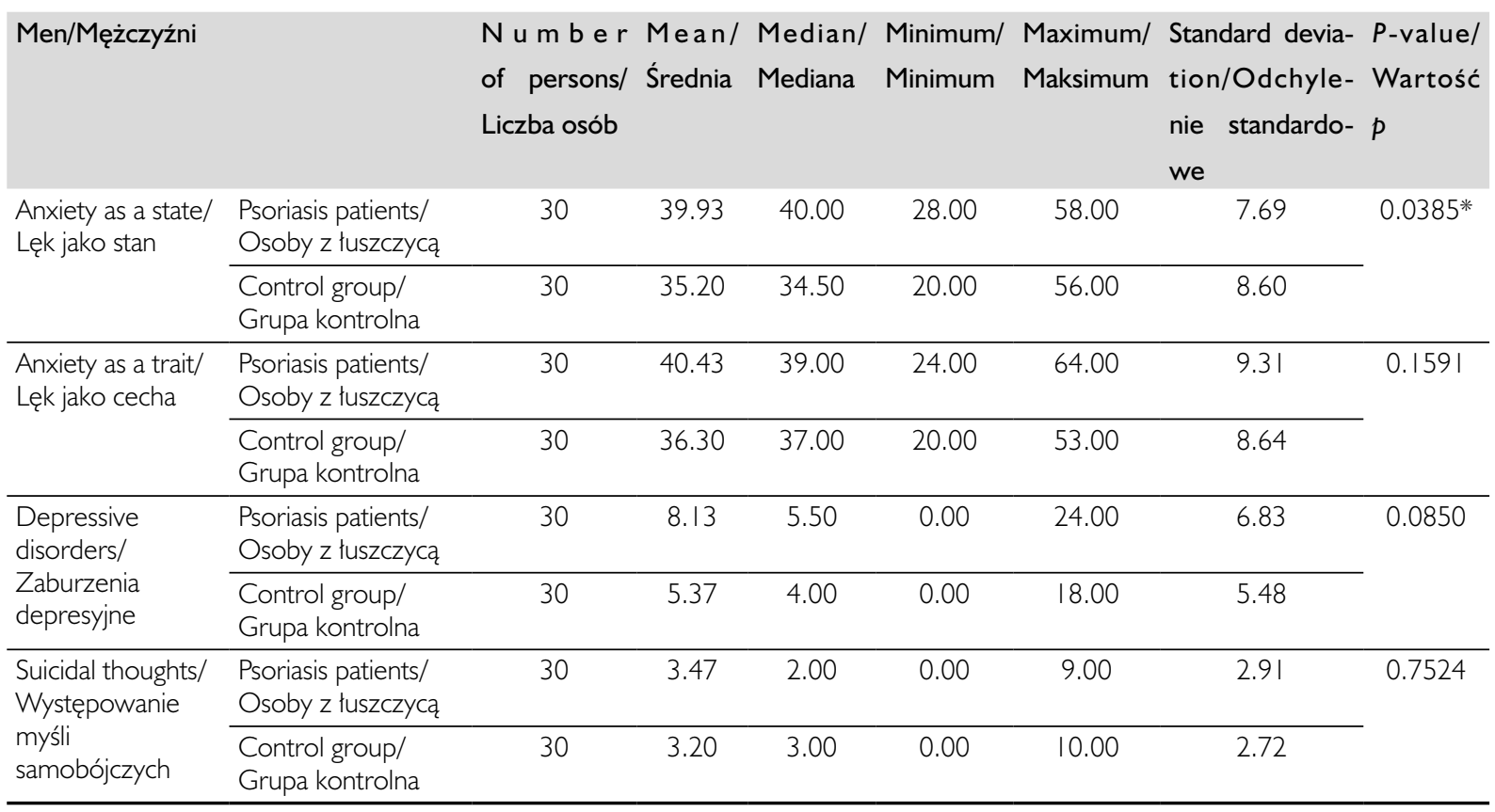

Source: own research/Źródło: badanie własne. ${ }^{*} p<0.05$; ${ }^{*} *$ p $<0.01$.

be attributed to the chronic nature of psoriasis - a disease considered to be shameful, vulnerable to stigmatization and evoking fear of being rejected by society [16]. Almost $60 \%$ of the psoriasis patients felt that people gazed at them due to their skin lesions and treated them like lepers who one should not touch to avoid infection [17]. Psoriasis patients have unpleasant experiences, e.g. when they are asked to leave a swimming pool or a gym and when they hear some unfavorable comments, especially in intimate situations. A fear of such experiences makes them avoid places and situations in which they would have to reveal their skin lesions [18, 19].

This research study did not demonstrate statistically significant differences between the healthy subjects and the psoriasis patients with regard to anxiety as a trait, which suggests that in the case of the psoriasis-affected persons anxiety was a result of the disease rather than a permanent personality feature.

It was established that the persons with psoriatic lesions showed a significantly higher level of depressive disorders compared to the control group. This finding is consistent with the results of a study on the relationship between psoriasis and depressive mood [20]. The contemporary beauty standard requires impeccable skin. Visible psoriatic lesions definitely do not meet such standards, and they often evoke disgust and revulsion. Awareness that one's appearance may cause such unpleasant reactions may contribute to lowering of one's self-esteem, mood and well-being, which in turn leads to ży dotykać z obawy przed zarażeniem [17]. Chorzy na łuszczycę są narażeni na negatywne doświadczenia - są proszeni o opuszczenie pływalni lub sali gimnastycznej, słyszą niepochlebne komentarze na swój temat, zwłaszcza w sytuacjach intymnych. Lęk przed takimi doświadczeniami powoduje, że starają się unikać miejsc i sytuacji, w których musieliby ujawnić zmiany chorobowe $[18,19]$.

W przeprowadzonym badaniu nie wykazano statystycznie istotnych różnic pomiędzy osobami zdrowymi i chorymi w zakresie lęku rozumianego jako cecha, co sugeruje, że w przypadku chorych na łuszczycę lęk jest wynikiem choroby, a nie stałą cechą osobowości.

U osób ze zmianami łuszczycowymi stwierdzono istotnie wyższy poziom zaburzeń depresyjnych niż $\mathrm{w}$ grupie kontrolnej. To ustalenie jest zgodne $\mathrm{z}$ wynikami badania dotyczącego związku łuszczycy i nastroju depresyjnego [20]. Obowiązujący dziś kanon piękna zakłada nienaganny wygląd skóry. Widoczne zmiany łuszczycowe znacznie odbiegają od standardów, co często wywołuje obrzydzenie i odrazę. Świadomość wyglądu, który może być przyczyną tego typu reakcji, przyczynia się do spadku samooceny, pogorszenia samopoczucia i nastroju, a także prowadzi do zaburzeń depresyjnych, które stwierdza się u 84\% chorych na łuszczycę [6].

Nasilenie objawów depresji spowodowanej łuszczycą może prowadzić do myśli i tendencji samobójczych. Potwierdzają to wyniki badania, które są zgodne z rezultatami badań wskazujących na występowanie myśli samobójczych u 7,2\% hospitalizowanych pacjentów 
depressive disorders that are diagnosed in $84 \%$ of psoriasis patients [6].

Exacerbation of depressive symptoms caused by psoriasis may lead to suicidal thoughts and tendencies. This is confirmed by the results this research, which are consistent with the results of studies showing that suicidal thoughts were present in $7.2 \%$ of hospitalized psoriasis patients and in $2.5 \%$ of psoriasis outpatients [8]. Other studies showed that $25 \%$ of psoriasis patients at least once wanted to commit suicide because of the disease; $8 \%$ claimed that life with psoriasis was not worth living, and almost $2 \%$ had made a suicide attempt or committed an act of self-mutilation [21].

This research study did not confirm any difference between the two groups of women in terms of anxiety as a state and as a trait. This may mean that women affected by psoriasis are able to adapt to the tough situation, effectively masking their skin lesions by means of appropriate clothes, hair-do or make-up. It was observed that half of the patients chose to wear light-colored clothes that covered their skin lesions [17]. Another reason why the women affected by psoriasis might not experience increased anxiety is the ability to obtain social support. Social support protects them from dissatisfaction with their appearance and from the need to adjust to the ideals of beauty dictated by culture. It was shown that women tended to surround themselves with friends and family, which helped them cope with stress and remain in a good mental state [21, 22]; consequently they experienced a lower level of anxiety compared to the men, and their mood deteriorated less often [23].

Simultaneously, significant discrepancies were identified between the healthy women and the female psoriasis patients in terms of tendencies to depression and suicidal thoughts. Basińska and Szymańska [20] also demonstrated that the female psoriasis patients more often were weary and less vigorous, and experienced a lowered mood. The condition of skin is important for most women, and its unfavorable appearance may lead to a decrease in self-esteem, to depression and suicidal thoughts [24]. It was observed that occurrence of psoriatic lesions in the area of private parts had a particularly negative effect on the women's mood [25].

Another conclusion drawn from the research study makes it possible to find a difference between the healthy men and male psoriasis patients in terms of anxiety as a state. This means that, compared to the women, the psoriasis-affected men were characterized by a lower level of adaptive abilities and less skill in masking their skin lesions. Visible symptoms evoke feelings of stigmatization and fear of experiencing various forms of ostracism. This conclusion was confirmed in a study involving a group of men with considerably intensive psoriatic lesions [26], who often heard some stigmatizing comments suggesting that their skin condition was an effect of AIDS, leprosy or venereal diseases. z łuszczycą oraz u 2,5\% leczonych ambulatoryjnie [8]. W innych badaniach wykazano, że $25 \%$ chorych na łuszczycę przynajmniej raz w życiu pragnęło odebrać sobie życie z powodu choroby, $8 \%$ twierdziło, że nie warto żyć z łuszczycą, a prawie $2 \%$ dokonało próby samobójczej lub samookaleczenia [21].

W badaniu nie stwierdzono, żeby lęk jako stan i jako cecha różnicował porównywane grupy kobiet. To pozwala przypuszczać, że kobiety chore na łuszczycę stosują aktywne strategie radzenia sobie i potrafią adaptować się do sytuacji trudnej, skutecznie maskując zmiany skórne poprzez odpowiedni ubiór, fryzurę i makijaż. Zaobserwowano, że połowa pacjentów wybiera odzież w jasnych kolorach, zakrywającą zmiany skórne [17]. Kolejnym powodem, dla którego kobiety w przebiegu łuszczycy mogą nie odczuwać wzmożonego lęku, jest umiejętność pozyskiwania wsparcia społecznego. Wsparcie społeczne chroni przed niezadowoleniem z własnego wyglądu oraz przed potrzebą dostosowania się do ideału piękna zdefiniowanego kulturowo. Dowiedziono, że kobiety chętnie otaczają się przyjaciółmi i rodziną, przez co zachowują dobrą kondycję psychiczną i radzą sobie ze stresem [21, 22], wykazują niższy niż mężczyźni poziom lęku i rzadziej doświadczają spadku nastroju [23].

Jednocześnie wykazano znaczące różnice pomiędzy kobietami zdrowymi i chorymi na łuszczycę pod względem skłonności do depresji oraz występowania myśli samobójczych. Basińska i Szymańska [20] stwierdziły również, że kobiety chore na łuszczycę częściej są znużone oraz mają obniżony nastrój i wigor. Stan skóry jest ważny dla większości kobiet, a jej niekorzystny wygląd może prowadzić do spadku poczucia własnej wartości, depresji i myśli samobójczych [24]. Zaobserwowano, że szczególnie negatywnie na nastrój kobiet wpływa obecność zmian łuszczycowych w miejscach intymnych [25].

Kolejny wniosek z przeprowadzonego badania to zróżnicowanie mężczyzn zdrowych i chorych na łuszczycę pod względem lęku jako stanu. To oznacza, że mężczyznom z łuszczycą należy przypisać mniejsze niż kobietom zdolności przystosowawcze i słabszą umiejętność maskowania zmian skórnych. Widoczne objawy łuszczycy wywołują poczucie stygmatyzacji i lęk przed doświadczaniem różnych form ostracyzmu. Ten wniosek znajduje potwierdzenie $\mathrm{w}$ badaniach przeprowadzonych u mężczyzn ze znacznym nasileniem zmian łuszczycowych [26], którzy często byli obiektem stygmatyzujących komentarzy sugerujących, że stan ich skóry jest spowodowany przez AIDS, trąd bądź choroby przenoszone drogą płciową.

W odróżnieniu od kobiet mężczyźni chorzy na łuszczycę nie różnią się od zdrowych mężczyzn pod względem zaburzeń depresyjnych i częstości występowania myśli samobójczych. To ustalenie nie jest zgodne $\mathrm{z}$ większością wyników badań na temat związku chorób prze- 
In contrast to the female psoriasis patients, the male ones did not differ from the healthy men in terms of depressive disorders or frequency of suicidal thoughts. This finding is not consistent with most research results concerning the relationship between chronic diseases and depressive disorders. However, Basińska and Szymańska [20] proved that the sick men much more often than the women experienced a positive mood and that they were more vigorous. This may be caused by different styles of experiencing depressive disorders by male and female psoriasis patients. Women fall into depressive moods when they feel they have no hope, help or support. Men, in turn, experience depression when they lose their satisfaction with life and the possibility to work [22].

\section{CONCLUSIONS}

From a psychosocial perspective, the most severe consequence of psoriasis is disturbance of interpersonal contacts. Sometimes psoriasis patients withdraw from society of their own will [27], although social isolation may be secondary to stigmatization. Solitude and social exclusion combined with the burden caused by the disease symptoms often lead to depression and exacerbate suicidal thoughts. As it was demonstrated in this research study, psoriasis may become a predictor of anxiety as a state (particularly among men), depressive disorders and suicidal thoughts (especially in the case of women). Despite the limitations of the present study, such as the fact that the list of questions in the questionnaire regarding suicidal ideation was formulated on the basis of textbook descriptions and the questionnaire itself has not been published or normalized, the results suggest that psychological counseling should play an important part in countering the long-term consequences of psoriasis. A psychologist's intervention should include motivating the patient to start treatment, assistance in adaptation to the disease and improving the life quality by effective coping with tension and stress $[9,11]$. wlekłych z zaburzeniami depresyjnymi. Jednak Basińska i Szymańska [20] dowiodły, że chorzy mężczyźni znacznie częściej niż kobiety odczuwali nastrój pozytywny oraz że cechował ich większy wigor. Może to wynikać z odmiennego stylu doświadczania zaburzeń depresyjnych przez chorych na łuszczycę mężczyzn i kobiety. Kobiety stają się depresyjne wówczas, gdy odczuwają brak nadziei i pomocy. Mężczyźni natomiast doświadczają depresji w momencie utraty satysfakcji z życia i możliwości wykonywania pracy [22].

\section{WNIOSKI}

Z perspektywy psychospołecznej najbardziej dotkliwą konsekwencją łuszczycy są zaburzenia w kontaktach interpersonalnych. Zdarza się, że chorzy z własnej woli wycofują się ze społeczeństwa [27], choć izolacja społeczna może być konsekwencją stygmatyzacji. Samotność i wykluczenie społeczne oraz uciążliwość objawów chorobowych często prowadzą do depresji i wzmagają chęć odebrania sobie życia. Jak wykazano w przeprowadzonym badaniu, łuszczyca może się stać predyktorem wystąpienia lęku jako stanu (szczególnie u mężczyzn), zaburzeń depresyjnych i myśli samobójczych (zwłaszcza u kobiet). Mimo ograniczeń opisywanego badania, do których można zaliczyć to, że listę pytań w ankiecie dotyczącej myśli samobójczych utworzono na podstawie opisów podręcznikowych, a ankieta nie była dotychczas publikowana i nie podlegała procesowi walidacji, wyniki sugerują, że w zwalczaniu długotrwałych skutków łuszczycy ważną rolę odgrywa pomoc psychologiczna. Interwencja psychologa powinna obejmować motywowanie pacjenta do podjęcia leczenia, pomoc w przystosowaniu się do choroby i poprawianiu jakości życia poprzez efektywne radzenie sobie $\mathrm{z}$ napięciem i stresem $[9,11]$

\section{KONFLIKT INTERESÓW}

Autorzy nie zgłaszają konfliktu interesów.

\section{CONFLICT OF INTEREST}

The authors declare no conflict of interest.

\section{References}

\section{Piśmiennictwo}

1. Łuczkowska M., Żaba R.: Łuszczyca. [In]: Psychologiczne i medyczne aspekty chorób skóry. T. Rzepa, J. Szepietowski, R. Żaba (eds.). Cornetis, Wrocław, 2011, 166-172.

2. Reich A., Hrehorow E., Szepietowski J.C.: Pruritus is an important factor negatively influencing the well-being of psoriatic patients. Acta Dermatovenereol 2010, 90, 257-263.

3. Bourne E.J.: Lęk i fobia. Praktyczny podręcznik dla osób z zaburzeniami lękowymi. Wydawnictwo Uniwersytetu Jagiellońskiego, Kraków, 2011. 
4. Leary M., Kowalski R.M.: Lęk społeczny. Gdańskie Wydawnictwo Psychologiczne, Sopot, 2001.

5. Steuden S., Okła W., Puchalska K.: Lęk jako zmienna modyfikująca poczucie jakości życia u osób chorych na łuszczycę. [In:] Jakość życia w chorobie. S. Steuden, W. Okła (Eds.), Wydawnictwo KUL, Lublin, 2006, 63-82.

6. Parafianowicz K., Sicińska J., Moran A., Szumański J., Staniszewski K., Rudnicka L., et al.: Współwystępowanie zaburzeń psychicznych w łuszczycy: doniesienie wstępne. Psychiatr Pol 2010, XLIV, 119-126.

7. Rachman S.: Zaburzenia lękowe. Gdańskie Wydawnictwo Psychologiczne, Sopot, 2005.

8. Gupta M.A., Gupta A.K.: Depression and suicidal ideation in dermatology patients with acne, alopecia areata, atopic dermatitis and psoriasis. Br J Dermatol 1998, 139, 846-850.

9. Denys K.: Psychologiczne aspekty leczenia chorób dermatologicznych. [In:] Zaburzenia psychosomatyczne w ujęciu terapeutycznym. A. Orzechowska, P. Gałecki (eds.), Continuo, Wrocław, 2014, 126-154.

10. Hammen C.: Depresja. Gdańskie Wydawnictwo Psychologiczne, Gdańsk, 2004.

11. Bogaczewicz A., Sobów T., Bogaczewicz J., Sysa-Jędrzejowska A., Woźniacka A.: Psychologiczne uwarunkowania jakości życia chorych na łuszczycę: doniesienia wstępne. Dermatol Klin 2010, 12, 205-210.

12. Cubała M.J., Jakuszkowiak-Wojten K., Barańska-Rybak W., Sokołowska-Wojdyło M.: Depresja w przebiegu łuszczycy: opis przypadku. Psychiatria 2006, 3, 138-142.

13. Gupta M.A., Schork N.J., Gupta A.K., Kirkby S., Ellis C.N.: Suicidal ideation in psoriasis. Int J Dermatol 1993, 32, 188-190.

14. Zawadzki B., Popiel A., Pragłowska E.: Charakterystyka psychometryczna polskiej adaptacji Kwestionariusza Depresji BDI-II Aarona T. Becka. Psychologia Etologia Genetyka 2009, 19, 71-95.

15. Beck A.T., Steer R.A., Brown G.K.: BDI-II. Beck Depression Inventory. Manual. The Psychological Corporation, San Antonio, 1996.

16. Rzepa T., Jakubowicz O., Witmanowski H., Żaba R.: Disease-induced level of shame in patients with acne, psoriasis and syphilis. Adv Dermatol Allergol 2013, 30, 233-236.

17. Janowski K.: Problematyka jakości życia w chorobach dermatologicznych. [In:] Jakość życia w chorobie. S. Steuden, W. Okła (eds.), Wydawnictwo KUL, Lublin, 2006, 49-62.

18. Gupta M.A., Gupta A.K.: Psoriasis and sex: a study of moderately to severely affected patients. Int J Dermatol 1997, 36, $259-262$.

19. Hawro T., Janusz I., Zalewska A., Miniszewska J.: Jakość życia i stygmatyzacja a nasilenie zmian skórnych i świądu u osób chorych na łuszczycę. [In:] Psychologiczne i medyczne aspekty chorób skóry. T. Rzepa, J. Szepietowski, R. Żaba (eds.). Cornetis, Wrocław, 2011, 42-47.

20. Basińska M.A., Szymańska L.: Zwiazzek nastroju z cechami choroby u osób z łuszczycą. Przegl Dermatol 2013, 100, 146-153.

21. Makara-Studzińska M., Lewicka M., Sulima M., Pietrzak D.: Występowanie depresji u kobiet chorych na łuszczycę w okresie okołomenopauzalnym a potrzeba wsparcia - przegląd literatury. Psych Psychol Klin 2012, 12, 120-124.

22. Łoza K., Borzęcki A., Cielica W., Łoza B.: Zaburzenia psychosomatyczne w przebiegu łuszczycy. Nowa Med 2003, 1, 34-38.

23. Hawro T., Miniszewska J., Chodakiewicz J., Sysa-Jędrzejowska A., Zalewska A.: Lęk i depresja, a wsparcie społeczne u chorych na łuszczycę. Przegl Lek 2007, 64, 568-571.

24. Skopińska S.: Piękna skóra wyznacznikiem dobrego samopoczucia i akceptacji społecznej. [In:] Psychologiczne i medyczne aspekty chorób skóry. T. Rzepa, J. Szepietowski, R. Żaba (eds.). Cornetis, Wrocław, 2011, 30-34.

25. Zamirska A., Reich A., Berny-Moreno J., Salomon J., Szepietowski J.C.: Vulvar pruritus and burning sensation in women with psoriasis. Acta Dermatovenereol 2008, 88, 132-135.

26. Gupta M.A.: Age and gender differences in the impact of psoriasis on quality of life. Int J Dermatol 1995, 34, 700-703.

27. Bishop G.D.: Jak radzić sobie z chorobą przewlekłą i upośledzeniem. [In:] Psychologia zdrowia. G.D. Bishop (ed.), Wydawnictwo Astrum, Wrocław, 2007, 322-354.

Received: 19.02 .2019

Accepted: 21.07.2019

Otrzymano: 19.02.2019 r.

Zaakceptowano: 21.07.2019 r.

How to cite this article

Stachecka M., Rzepa T.N., Furmańska J., Żaba R.W.: The occurrence of anxiety, depression, and suicidal thoughts in patients with psoriasis. Dermatol Rev/Przegl Dermatol 2019, 106, 486-494. https://doi.org/10.5114/dr.2019.89996. 